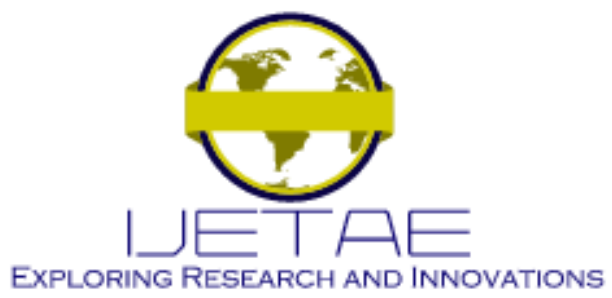

International Journal of Emerging Technology and Advanced Engineering

Website: www.ijetae.com (E-ISSN 2250-2459, Scopus Indexed, ISO 9001:2008 Certified Journal, Volume 11, Issue 12, December 2021)

\title{
Integration of Course Management and its Effect on Graduate Students' Learning
}

\author{
Jaime P. Pulumbarit \\ Bulacan State University, Malolos Bulacan Philippines
}

\begin{abstract}
The primary concern of this research study is the acceptance of a course managing system and its significant effect on students' learning in the graduate school. This study used the descriptive correlational method that make use of validated questionnaire as a source of data-gathering tool, demonstrated by extensive documentary analysis. The target client of the study were 225 graduate school students and 15 graduate school professors. The results were processed using the Statistical Packages for Social Sciences (SPSS) and the data were evaluated and interpreted using regression analysis in determining the acceptance of integrating a course managing system and its influence in the teaching and learning of students in the graduate school department. Using the said method, the outcomes of the study have shown that students from the graduate school is relatively ready to face the challenges of the fourth industrial revolution as proven by the utilization of cybergogy and level of acceptance of the course managing system. The academic profile of graduate school students demonstrates significant learning because of their efforts to do well in their academic subjects. In this study null hypothesis, states that the acceptance of using a course managing system does not significantly affect students' learning in the graduate school is rejected. The difficulties presented if recognized could lead to many opportunities design for innovative approach in teaching and learning. The implications derived based in the findings of the study are significant observations that can be considered in further advancement of the quality of teaching and learning in the graduate school.
\end{abstract}

Keywords: Integration of Course Management, Technology-Based Education, Online Learning,

\section{INTRODUCTION}

Technologies have brought major shifts in the world of education, such as shifting paradigms, from a closed model and a teacher-centered classroom to a more open and student-centered model that can stimulate students' analytical potential in information processing and that incorporates online learning, blended and interactive models [1].
Higher education institutions in the country encourage and embrace distance learning. Designing a Course Management System (CMS) that offers a range of resources and functions to promote study [2] and training. In school, the introduction of information technology (IS) is considered costly and often ineffective due to low levels of device consumer adoption [3]. For this reason, IS research has centered, in part, on variables that lead to the adoption of the device or technology by the consumer. As part of this important initiative, Davis has theorized and validated the Technology Adoption Model (TAM) to describe how the features of the device customer have led to the effect of evaluating trends in the use of technology. Since then, TAM has faced empiric analysis in a number of contexts [3], [4]. The feasibility of TAM has stimulated the ongoing study of its applicability, modifications and extensions. Many of the changes considered have a common emphasis on client side variables exogenous to the original model [5].

The analysis is logically supported the Technology Acceptance Paradigm (TAM) and therefore the Principle of Expected Actions (TBP), that notes that client acceptance of information in technology is outlined by 2 concepts: perceived utility and perceived easy use. the previous is represented because the degree to which an individual believes that employing a explicit system would improve the performance of his/her job." Thus, high-perceived utility technology suggests that customers believe an honest life.

Usage-Performance arrangement. The above refers to the degree to which the prospective user expects the target system to be effortless." When one program is considered to be better to use than another, one is more likely to be approved [4]. In the meantime the TPB contains more TAM constructs: attitude towards use, encouraging situations, subjective norm and behavioural purpose to use [6]. 


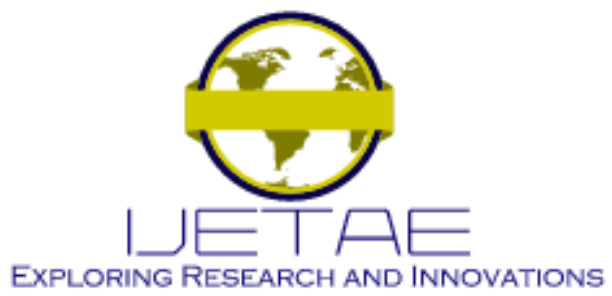

International Journal of Emerging Technology and Advanced Engineering Website: www.ijetae.com (E-ISSN 2250-2459, Scopus Indexed, ISO 9001:2008 Certified Journal, Volume 11, Issue 12, December 2021)

The research therefore measured the adoption of CMS incorporation and its effect on graduate students' learning. Acceptance of the integration of a course management framework was measured in terms of its effectiveness, ease of use, attitudes towards use, encouraging circumstances, subjective standard and behavioural intent to use. In the meantime, graduate students were assessed using their grades in key subjects, main subjects and cognate subjects, respectively [7].

\section{RESEARCH METHOD}

The descriptive-correlational method of research was utilized in the study to determine the acceptance of integrating a course management system [8], [9] in the graduate school and its effect on students' learning. A correlational research systematically investigates the relationship among variables as well as in determining the cause and effect relationship [10]. The study made use of a quantitative research approach in analyzing and understanding the effects of acceptance of integrating a course management system on students' learning.

The target client of the study were students and professors in a higher education institution for school year 2018-2019. Table 1 shows the distribution of professors and graduate students at graduate school department.

Purposive sampling was used in selecting the respondents of the study. The respondents were selected based on the following criteria:

- Professors and students are knowledgeable and users of the course management system; and

- Respondents have been users of the CMS for at least one semester.

In addition, each professor has a class size of 15 , which yielded 225 graduate students for 15 professors.

Table 1.

Respondents of the Study

\begin{tabular}{ccc}
\hline Respondents & & \\
\cline { 2 - 3 } & F & \% \\
\hline Professors & 15 & 6.25 \\
Graduate Students & 225 & 93.75 \\
\hline Total & $\mathbf{2 4 0}$ & $\mathbf{1 0 0}$ \\
\hline
\end{tabular}

In addition, each professor has a class size of 15 , which yielded 225 graduate students for 15 professors. This research used a standardized instrument for the acceptance of the integration of a course management method in a graduate school. The instrument was adapted from the [11] entitled "Examination of the intention to use technology among pre-service teachers: integration of the technology acceptance model and the theory of planned behavior" published in the Interactive Learning Environments journal, with an overall internal reliability coefficient of.82.

Acceptance of the integration of a course management framework was measured in terms of its effectiveness, ease of use, attitudes towards use, encouraging circumstances, subjective standard and behavioural intent to use [12], [13]. The internal accuracy of Cronbach's alphas for these elements was.83,.90,.87,.82,.80 and.70, respectively, and was appropriate.

In the meantime, graduate students were assessed using their grades in key subjects, main subjects and cognate subjects, respectively. The data collected were tabulated and processed using the Statistical Packages for Social Sciences (SPSS). In order to analyze and interpret the data gathered, the following statistical measures were used:

The Acceptance of Integration for Course Management System was quantified using the following scale:

$\begin{array}{lrl}\text { Rating Scale } & \text { Range } & \text { Descriptive Evaluation } \\ 5 & 4.50-5.00 & \text { Very great extent } \\ 4 & 3.50-4.49 & \text { Great extent } \\ 3 & 2.50-3.49 & \text { Moderate extent } \\ 2 & 1.50-2.49 & \text { Least extent } \\ 1 & 1.00-1.49 & \text { Not at all }\end{array}$

Students' learning in core subjects, major subjects, and cognate subjects was analyzed using frequency counts and percentage procedures using the following:

$\begin{array}{lc}\text { Grade } & \text { Descriptive Evaluation } \\ 1.0 & \text { Outstanding } \\ 1.25 & \text { Very satisfactory } \\ 1.5 & \text { Satisfactory } \\ 1.75 & \text { Fairly satisfactory } \\ 2.0 & \text { Passed }\end{array}$

Problems encountered in the integration of CMS were analyzed using frequency counts and ranking procedures. The effects of acceptance of CMS integration on students' learning were quantified using correlation and regression analysis. 


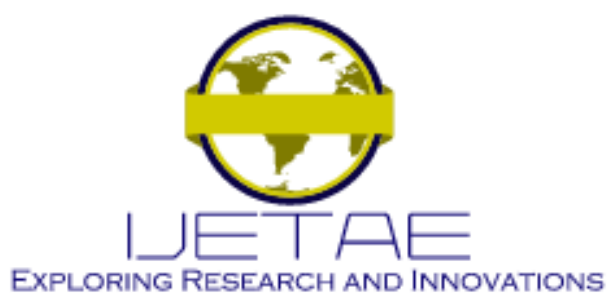

International Journal of Emerging Technology and Advanced Engineering Website: www.ijetae.com (E-ISSN 2250-2459, Scopus Indexed, ISO 9001:2008 Certified Journal, Volume 11, Issue 12, December 2021)

\section{RESUlts AND ANALYSIS}

In this study, the acceptance of integrating a course managing system resulted to a great extent in terms of its perceived usefulness (4.84), ease of use (4.31), attitudes towards use (4.42), facilitating conditions (4.19), subjective norm (4.19), and behavioral intention to use (4.49). These were presented in Tables 2.

\subsection{Acceptance of Course Management System}

Perceived Usefulness. The data in Table 2 presented great extent of perceived usefulness of course management system integration as shown by the average value of 4.48 . The perceived usefulness of CMS was manifested by its being able to enhance the respondents' effectiveness (4.42) and by its ability to increase their productivity.

Perceived Ease of Use. In terms of perceived ease of use, Table 3 depicts that the respondents are in agreement that CMS can easily be utilized to a great extent as evidenced by the average value of 4.31. Perceived ease of use of CMS was evident when the respondents agree that their interaction with course management system is clear and understandable (4.19), they find it easy to get along with course management system to do what they want to do (4.35), and they find CMS easy to use (4.38).

Attitude Towards Use. It may be gleaned that the respondents' attitude towards use of course management system was to a great extent as shown by the average value of 4.42. The respondents agree that the course management system makes life more interesting (4.46), Working with course management system is fun (4.38), they like using course management system (4.46), and they look forward to those aspects in their life that require them to use the CMS (4.38).

Facilitating Conditions. Reveals that the facilitating of course management system integration was also to a great extent as shown by the average value of 4.19. Facilitating conditions were evident when guidance is available whenever they need help to use Course Management System (4.19), when they need to use course management system, a specialized instruction is available to them (4.12), and when they need to use the course management system, a specific person is available to provide assistance (4.27).

Subjective Norm. In terms of subjective norm, the data in Table 6 revealed that it is present in the institution to a great extent as shown by the average value of 4.19 .
This is evident by the people whose opinions they value encourage them to use course management system (4.19) and people who are important to them give support to use course management system.

Behavioral Intention to Use. The behavioral intentions to use was to a great extent as evidenced by the average value of 4.49. These were indicated by the respondents' intention to use course management system in the future (4.49) and plan to use course management system often (4.49).

\subsection{Graduate Students Academic Learning}

Analysis of data in Table 2 would show that the graduate students' academic learning was very satisfactory in core, major, and cognate subjects as evidenced by the mean value of 1.20 with a standard deviation of .07. Furthermore, about 60 or $26.56 \%$ recorded an outstanding academic performance (1.0), 148 or $65.78 \%$ got a very satisfactory performance (1.25), and only 17 recorded a satisfactory performance (1.5). No one registered a fairly satisfactory or passing performance. This means that the graduate students are exerting their best efforts to perform well in their academic subjects.

Table 2.

Graduate Students' Academic Learning in Core, Major, and Cognate Subjects

\begin{tabular}{lcc}
\hline \multicolumn{1}{c}{ Grades } & Frequency & Percentage \\
\hline 1.0 (Outstanding) & 60 & 26.67 \\
1.25 (Very Satisfactory & 148 & 65.78 \\
1.5 (Satisfactory) & 17 & 7.55 \\
1.75 (Fairly Satisfactor: & 0 & 0 \\
2.0 (Passed) & 0 & 0 \\
\hline \multicolumn{1}{c}{ Total } & $\mathbf{2 2 5}$ & $\mathbf{1 0 0}$ \\
& Mean = 1.20 (Very Satisfactory ) \\
\multicolumn{2}{c}{ Standard Deviation = .07 } \\
\hline
\end{tabular}

3.3 Effects of Course Management System Acceptance on Students' Learning

In conducting the study, it was hypothesized that the acceptance of integrating a course managing system does not significantly affect graduate students' learning. To determine the extent of effects of the acceptance factors on the academic learning of graduate students, the data were subjected to regression analysis [14]-[16].

Results of the regression in Table 3 revealed that of the four dimensions of course management system acceptance namely ease of use, attitudes towards use, facilitating conditions, and intention to use produced B coefficients of $.736, .709, .920$ and .803 , respectively with associated probability less than the significance level set at .05. 


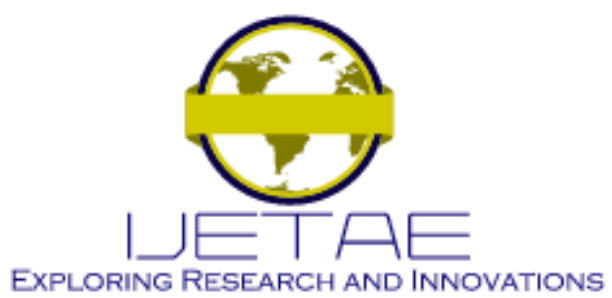

International Journal of Emerging Technology and Advanced Engineering Website: www.ijetae.com (E-ISSN 2250-2459, Scopus Indexed, ISO 9001:2008 Certified Journal, Volume 11, Issue 12, December 2021)

The findings indicate that for every unit increase in the acceptance of using a course managing system could generate $.461, .501, .356$, and .674 increases in the academic learning of graduate students. Meanwhile, the factors perceived usefulness (.003) and subjective norm (.061) also contributed to graduate students' learning but not to a significant extent.

The obtained F-value of 3.545 which was found significant at .05 alpha indicates that the acceptance of using a course managing system in terms of perceived usefulness, ease of use, attitudes towards use, facilitating conditions, subjective norm, and behavioral intention to use formed a very significant set of predictors for the academic learning of graduate students in core, major, and cognate subjects. In other words the integration of a course management system in the graduate school can be considered as an effective strategy in educating the $21^{\text {st }}$ century students.

\subsection{Problems Encountered in the Utilization of a Course Management System}

The study reveals that integrating a course management system in the graduate education has encountered struggles or problems during its implementation [17]. The most common problem was that some professors in the graduate school are not yet oriented on the use of course management system $\left(102,1^{\text {st }}\right)$. This followed by the struggle that mass training on the use of course management system is not yet fully implemented $\left(91,2^{\text {nd }}\right)$ and course management system is not yet available using mobile applications $\left(47,3^{\text {rd }}\right)$.

The problems presented if given immediate attention could lead to a lot of opportunities for innovative teaching and learning.

\subsection{Implications Drawn from the Results of the Study}

A number of insights were drawn from the findings of the study such as:

- The use of a course management system is very helpful especially for the students in the graduate school who are currently employed at the same. This will address their busy schedule concerns by lessening the number of contact hours during Saturdays.

- Independent learning will be realized through the utilization of course management system. The use of cybergogy shall be used at its maximum level.
- Although integrating a course management system was found to be valuable, it is still suggested that rather than replacing traditional with course management system, the benefits of both instructional techniques could be realized through mixed-mode instruction in which faceto-face instruction is enhanced by using the Web [18]. Such a mixed mode of interaction usually consists of traditional classroom instruction augmented by using a CMS that enables students to - among other thingscontinue discussion of course concepts and cases outside the classroom using a bulletin board; conduct group work on-line through chat rooms; take tests online; and access taped lectures, handouts, assignments, records, and grades on-line. Graduate school subjects like Methods of Research and Statistics can still be appreciated if a teacher is still providing inputs though face-to-face discussions.

\section{CONCLUSION}

In the light of the findings of the study, the following conclusions were drawn:

Table 3.

Regression Analysis of Course Management SystemAcceptance on Graduate Students' Learning

\begin{tabular}{|c|c|c|c|c|c|}
\hline \multirow[b]{2}{*}{ Indicators } & \multicolumn{2}{|c|}{$\begin{array}{l}\text { Unstandardized } \\
\text { Coefficients }\end{array}$} & \multirow{2}{*}{$\begin{array}{c}\text { Standardized } \\
\text { Coefficient } \\
\text { Beta } \\
\end{array}$} & \multirow{2}{*}{$\mathrm{T}$} & \multirow{2}{*}{$\begin{array}{l}\mathrm{P}- \\
\text { value }\end{array}$} \\
\hline & B & S.E & & & \\
\hline & 1.20 & & & & \\
\hline $\begin{array}{l}\text { (Constant) } \\
\text { perceived }\end{array}$ & 9 & .318 & & 3.796 & .000 \\
\hline usefulness & .003 & .130 & .004 & .022 & $\begin{array}{l}.982 \\
.003\end{array}$ \\
\hline $\begin{array}{c}\text { ease of use } \\
\text { attitudes }\end{array}$ & .736 & 149 & .461 & 3.091 & $\begin{array}{l}* \\
.004\end{array}$ \\
\hline towards use & .709 & .169 & .501 & 2.970 & $*$ \\
\hline $\begin{array}{l}\text { facilitating } \\
\text { conditions }\end{array}$ & .924 & 0.713 & .356 & 5.503 & $\begin{array}{l}.000 \\
*\end{array}$ \\
\hline $\begin{array}{l}\text { subjective } \\
\text { norm }\end{array}$ & .061 & 0.744 & .049 & 0.755 & .451 \\
\hline $\begin{array}{c}\text { behaviora } \\
1 \text { intention to } \\
\text { use }\end{array}$ & .803 & 69.15 & .674 & $\begin{array}{c}13.19 \\
2\end{array}$ & $\begin{array}{l}.000 \\
*\end{array}$ \\
\hline \multicolumn{6}{|c|}{ R-squared - .724 } \\
\hline \multicolumn{6}{|c|}{ F-value -3.545} \\
\hline \multicolumn{6}{|c|}{ p-value - .000 } \\
\hline \multicolumn{6}{|c|}{ alpha -0.05} \\
\hline
\end{tabular}




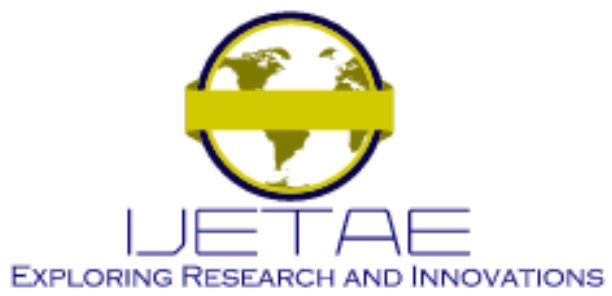

International Journal of Emerging Technology and Advanced Engineering

Website: www.ijetae.com (E-ISSN 2250-2459, Scopus Indexed, ISO 9001:2008 Certified Journal, Volume 11, Issue 12, December 2021)

1. The graduate school department is more or less ready to face the challenges of industrial revolution 4.0 as manifested by the utilization of cybergogy and great extent of acceptance of a course management system.

2. The academic profile of students in the graduate school department demonstrates quality learning due to their efforts to perform well in their subjects.

3. The null hypothesis, states that acceptance of a course managing system does not significantly affect graduate students' learning was rejected.

4. The problem brought up in this study if given immediate consideration could lead to opportunities towards advancing teaching and learning.

5. The implications gathered from the findings of the study are significant insights that can be considered in further upgrading the quality of teaching and learning in the graduate school.

\section{Acknowledgments}

I would like to express my gratitude to Bulacan State University, Research Office and to our University President Dr. Cecila N. Gascon for their constant support and assistance.

\section{REFERENCES}

[1] S. J. R. Manglapuz and L. L. Lacatan, "Academic management android application for student performance analytics: A comprehensive evaluation using ISO 25010:2011," Int. J. Innov. Technol. Explor. Eng., vol. 8, no. 12, pp. 5085-5089, 2019, doi: 10.35940/ijitee.L2735.1081219.

[2] E. L. Piol, L. L. Lacatan, and J. P. Pulumbarit, "Predictive Analysis of the Enrolment of Elementary Schools Using Regression Algorithms," Int. J. Emerg. Technol. Adv. Eng., vol. 11, no. 11, pp. 184-188, 2021, doi: 10.46338/ijetae1121.

[3] S. Alalshaikh, "Cultural Impacts on Distance Learning Online Learning Styles and Design," vol. 16, no. 3, pp. 67-75, 2015.

[4] D. Albayrak and Z. Yildirim, "Using social networking sites for teaching and learning: Students' involvement in and acceptance of facebook ${ }^{\circledR}$ as a course management system,” J. Educ. Comput. Res., vol. 52, no. 2, pp. 155-179, 2015, doi: 10.1177/0735633115571299.

[5] B. C. Czerkawski and E. W. Lyman, "An Instructional Design Framework for Fostering Student Engagement in Online Learning Environments," TechTrends, vol. 60, no. 6, pp. 532-539, 2016, doi: 10.1007/s11528-016-0110-z.

[6] L. L. Lacatan, "Hybrid Method and Face to Face Method in Teaching Mathematics : Effects on Students 'Performance," vol. 3, no. 2, pp. 143-146, 2013, doi: 10.7763/IJIET.2013.V3.252.
[7] J. N. Mindoro, N. U. Pilueta, Y. D. Austria, L. Lolong Lacatan, and R. M. Dellosa, "Capturing Students' Attention through Visible Behavior: A Prediction Utilizing YOLOv3 Approach," 2020 11th IEEE Control Syst. Grad. Res. Colloquium, ICSGRC 2020 - Proc., no. August, pp. 328-333, 2020, doi: 10.1109/ICSGRC49013.2020.9232659.

[8] T. Unwin et al., "Digital learning management systems in Africa: Myths and realities," Open Learn., vol. 25, no. 1, pp. 5-23, 2010, doi: 10.1080/02680510903482033.

[9] G. Veletsianos, R. Kimmons, and K. D. French, "Instructor experiences with a social networking site in a higher education setting: Expectations, frustrations, appropriation, and compartmentalization,” Educ. Technol. Res. Dev., vol. 61, no. 2, pp. 255-278, 2013, doi: 10.1007/s11423-012-9284-z.

[10] A. Fields, K. W. Lai, J. (Jack) Gibbs, A. Kirk, and J. Vermunt, "The transformation of an online learning community from an organised facility to an organic fraternity," Distance Educ., vol. 37, no. 1, pp. 60-72, 2016, doi: 10.1080/01587919.2016.1158769.

[11] R. A. Ellis and A. M. Bliuc, "An exploration into first-year university students' approaches to inquiry and online learning technologies in blended environments," Br. J. Educ. Technol., vol. 47, no. 5, pp. 970-980, 2016, doi: 10.1111/bjet.12385.

[12] A. K. M. N. Islam, "The moderation effect of user-type (educators vs. students) in learning management system continuance," Behav. Inf. Technol., vol. 34, no. 12, pp. 1160-1170, 2015, doi: 10.1080/0144929X.2015.1004651.

[13] Y. J. Joo, N. Kim, and N. H. Kim, "Factors predicting online university students' use of a mobile learning management system (m-LMS)," Educ. Technol. Res. Dev., vol. 64, no. 4, pp. 611-630, 2016, doi: 10.1007/s11423-016-9436-7.

[14] M. W. Sanga, "An Analysis of Technological Issues Emanating from Faculty Transition to a New Learning Management System.," Q. Rev. Distance Educ., vol. 17, no. 1, pp. 11-21, 2016.

[15] N. M. Radwan, M. B. Senousy, and A. E. D. Alaa El, “A new expert system for learning management systems evaluation based on neutrosophic sets," Expert Syst., vol. 33, no. 6, pp. 548-558, 2016, doi: $10.1111 /$ exsy. 12170.

[16] G. S. Sparrow, "A Model of Sustainability for Professional Organizations: Using a Learning Management System to Offer Continuing Education," Adult Learn., vol. 28, no. 2, pp. 79-81, 2017, doi: 10.1177/1045159515595067.

[17] Q. Wang, H. L. Woo, C. L. Quek, Y. Yang, and M. Liu, "Using the Facebook group as a learning management system: An exploratory study,” Br. J. Educ. Technol., vol. 43, no. 3, pp. 428-438, 2012, doi: 10.1111/j.1467-8535.2011.01195.x

[18] Alexen A. Elacio; Luisito L. Lacatan; Albert A. Vinluan; Francis G. Balazon, "Machine Learning Integration of Herzberg's Theory using C4.5 Algorithm ," Int. J. Adv. Trends Comput. Sci. Eng., vol. 9, no. 1.1, pp. 57-63, 2020, doi: 10.30534/ijatcse/2020/1191.12020. 